Apidologie, 1983, 14 (2), 87-92

\title{
REGULATION OF HONEY BEE HOARDING EFFICIENCY
}

\author{
Thomas E. RINDERER \\ Bee Breeding and Stock Center Laborator:, A.R.S., U.S.D.A., \\ Baton Rouge. Louisiana 70808
}

\begin{abstract}
SUMMARY
Increased amounts of empty comb caused significant increases in the efficiency of hoarding from feeders containing sucrose solution $(P<0.01)$. This supports the hypothesis that empty comb volatiles in honey bee nests regulate the acceptance of nectar sources by honey bee nectar foragers across seasonally varying conditions of nectar availability.
\end{abstract}

Empty comb in honey bee nests, through volatiles it releases (RINDERER, 1981), strongly influences the nectar harvesting of bees (RINDERER and BAXTER, 1978, 1979, 1980; RINDERER, 1982). These studies have examined increases in the intensity of both hoarding in laboratory cages (FREE and WiLLIAMS, 1972; KULINCEVIC and ROTHENBUHLER, 1973) and foraging activities of bees in field conditions caused by increased amounts of empty comb. In addition to intensity, another feature of nectar harvesting is influenced by empty comb. In a study using varied concentrations of sucrose solution as food at feeding stations, a majority of trained bees from nests with small amounts of empty comb collected less concentrated food, while a majority of trained bees from nests with large amounts of empty comb rejected less concentrated food (RINDERER, 1982). These results suggest that empty comb also regulates foraging efficiency in honey bees and that more efficient bees are more highly selective nectar-foragers. This experiment was designed to determine if the hoarding efficiencies of bees in laboratory cages differ as a result of having differential amounts of empty comb.

\section{MATERIALS AND METHODS}

Combs of emerging adult worker bees were collected from the brood nests of six colonies and held in an incubator $\left(35^{\circ} \mathrm{C} ; 50 \% \mathrm{RH}\right)$ until the bees were $0-24 \mathrm{~h}$ old. The bees were then placed into 
laboratory hoarding cages fitted with either one or three pieces of comb having totals or 47 to $141 \mathrm{~cm}$ of exposed surface area. Bees from each colony were caged separately, by groups of 30, in four of each type of cage. These cages had four feeders. Identical gravity feeders contained either $20 \%(\mathrm{w} / \mathrm{w})$ sucrose in water solution, $50 \%$ sucrose solution, or water. The fourth feeder held a pollen substitute. After being stocked with bees, cages were placed in an incubator $(35 \circ \mathrm{C} ; 50 \% \mathrm{RH})$ and inspected daily for seven days: the amounts of sucrose solution removed from the feeders were measured and feeders were replenished.

This experimental design, giving bees simultaneous access to different sucrose solutions, permitted estimates of hoarding efficiency. These estimates of reward per unit of work were calculated as total grams of sugar hoarded divided by total grams of solution hoarded, and could range from 0.2 (only $20 \%$ solution was hoarded) to 0.5 (only $50 \%$ solution was hoarded). Portions of efficiency estimates derived from the hoarding of the $20 \%$ solution probably inflate the overall efficiency estimate somewhat, since bees tend to take smaller loads of lower quality food (VON FRISCH, 1967). Thus, any differences in efficiency are likely to be more extreme than calculated by this method.

\section{RESULTS}

Differential amounts of empty comb had several effects on hoarding (Table 1). Bees in all cages hoarded substantial amounts of $20 \%$ sucrose solution $(\bar{x} \pm$ S.E. $=15.8 \pm 1.6 \mathrm{~g})$ although they did hoard more $50 \%$ solution $(\bar{x} \pm$ S.E. $=28.7 \pm 1.8 \mathrm{~g})(\mathrm{F}=43.9 ; 1,72 \mathrm{df} ; \mathrm{P}<0.001)$. Bees in cages with three pieces of comb had a hoarding efficiency of 0.40 while bees in cages with one piece of comb had a significantly lower efficiency of $0.38(\mathrm{P}<0.003)$. Thus, bees with more comb hoarded an average of 51 grams of sucrose solution while bees with less comb hoarded a significantly smaller average of 38 grams of solution ( $\mathrm{P}<0.001)$. Differences in grams of sugar hoarded followed differences in grams of solution hoarded $(\mathrm{P}<0.001)$.

Bees from different colonies hoarded different amounts of solution and sucrose $(\mathrm{P}<0.01)$ but hoarded with similar efficiencies $(P=0.59)$ (Table 1). In the analysis of grams of solution and grams of sucrose, significant interactions $(P<0.01)$ occurred between the variables of amount of comb and colonies supplying bees. Thus, while bees from different colonies all increased hoarding in the presence of additional comb, they did so to different degrees. However, in the analysis of efficiency, the comparable interaction term was not significant indicating that increases in hoarding efficiency displayed by bees from all colonies were similar.

\section{DISCUSSION}

Crowding at the $50 \%$ solution feeder might be suspected of causing bees to use the $20 \%$ feeder and thereby reduce efficiency estimates. However, the largest amount removed from any feeder in any single day was $17 \mathrm{~g}$. Assuming an average load size of 61 "g, 17 grams would be removed in 278 hoarding trips or an average of less than 12 trips per hour. SYLVESTER et al. (1982) observed bees collecting 94 $\mu \mathrm{g}$ of $50 \%$ sucrose solution from open feeders in less than five minutes. Since at least three bees can simultaneously use a hoarding cage feeder, it is unlikily that the results are influenced by crowding.

The differential hoarding efficiencies observed in this experiment may arise from differential « decisions" (WADDINGTON and HOLDEN, 1979) regarding food quality. «Decisions » regarding food or forage quality can be interpreted as a set 


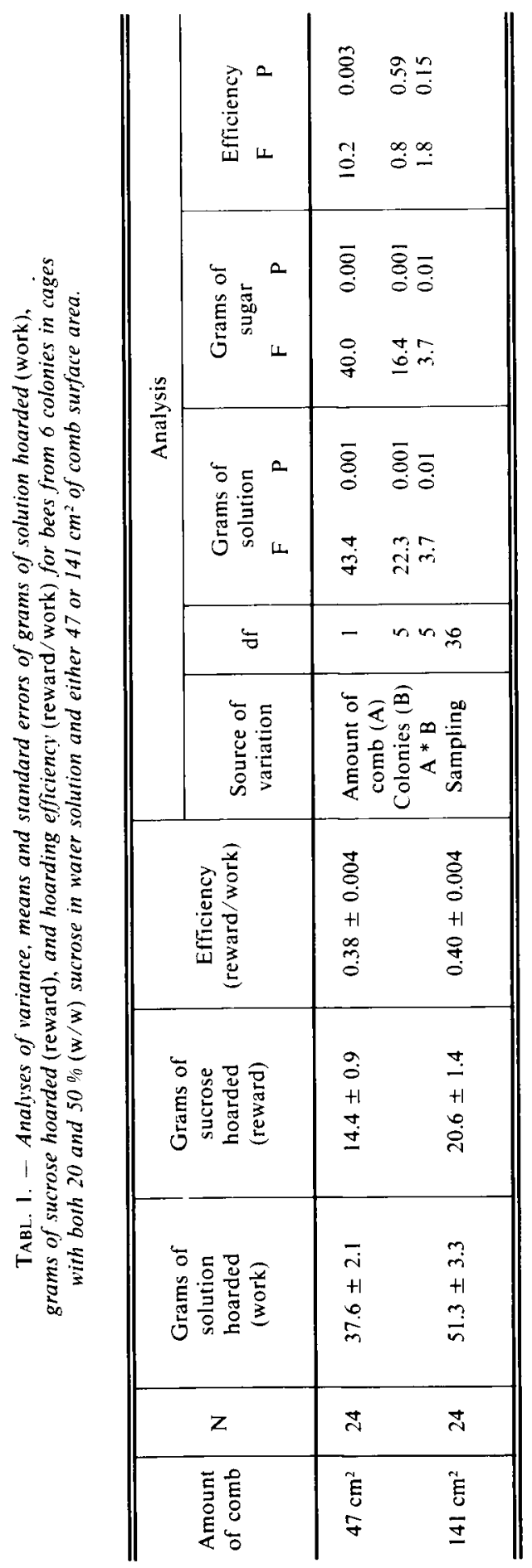


of physiological conditions and resulting processes which mediate measurable behaviour such as hoarding efficiency. Presumably, equal proportions of bees in cages with one and three combs found the feeder with $20 \%$ sucrose solution before they found the feeder with $50 \%$ solution. If bees in cages with three comb pieces had a greater tendency to reject the $20 \%$ solution and not hoard it, differential efficiency would result. If these bees later encountered and hoarded the $50 \%$ solution, differential hoarding efficiency would be enhanced.

A likely function of regulated hoarding efficiency is clear in the context of seasonally varying nectar availability (CRANE 1975; OERTEL et al., 1980; RINDERER, 1982). Communities of plants that evolved with honey-bees in temperate areas begin producing nectar in the spring. Initially, nectar sources tend to be both few and to secrete small amounts of moderately concentrated nectar. This changes rapidly, and by late spring to early summer, nectar sources usually are varied with some secreting large amounts of more highly concentrated nectar. A decline in variety of sources as well as their nectar secretion follows until by late summer there are only a few nectar sources available, nearly all of which secrete small amounts of relatively dilute nectar. In unmanaged honey bee nests the amount of empty storage comb, which also varies seasonally, coincides with changes in nectar availability. The largest amount of empty comb occurs at the beginning of the major period of nectar secretion and availability. Empty comb, through the action of volatiles it releases (RINDERER, 1981) may regulate shifts in foraging " decisions " which lead to bees selectively foraging at better nectar sources in late spring but also foraging at any available sources later in the season.

Differential hoarding efficiency in laboratory cages does not affect dance communication since bees do not dance in the cages. However, occurrences and durations of dances by bees foraging in the field are altered in the presence of additional empty comb (RINDERER, 1982). The nature of these alterations suggests that the use of dance language is seasonally regulated by comb volatiles. Also, the common exposure to comb volatiles by all bees in a colony at a given time may lead to similar foraging and dancing " decisions". Similar " decisions " are necessary for dance communication to effectively contribute to selective foraging (WADDINGTON, 1981). Hive bees receive nectar loads and through speed of receipt and rapidity of antennal drumming provide foragers with information on relative nectar quality (LiNDAUER, 1948; BOCH, 1957). These hive bees must be reasonably uniform in their varied responses to different nectars regardless of their experience in receiving nectar. Foragers must integrate information from bees receiving nectar with individually obtained information of foraging " costs ". This process must be reasonably uniform between foragers. Only if uniformity exists (WADDINGTON, 1981) can the dances of different honey bees accurately communicate the relative " profitability " of different nectar sources through differential dance duration (vON FRISCH, 1967) and differential acoustical burst frequencies (ESCH, 1961a, 1961b). 
The effect of comb on both hoarding efficiency and intensity, the seasonal shifts in empty comb availability which parallel seasonal shifts in nectar availability, and the common exposure to comb volatiles by all bees in a colony collectively suggest that comb volatiles have a major role in the regulation of honey bee foraging.

\title{
ACKNOWLEDGMENTS
}

I thank K. D. Waddington, A. B. Bolten, R. Boch and H. S. Shimanuki for useful comments on early manuscript drafts. This research was done in cooperation with Louisiana Agricultural Experiment Station.

Received for publication in October 1982.

\author{
RÉSUMÉ \\ RÉGULATION DE L'EFFICACITÉ DU HOARDING \\ (AMASSEMENT DE NOURRITURE) CHEZ L'ABEILLE
}

Une expérience précédente faite en conditions naturelles a suggéré que l'adjonction de rayons vides dans une colonie augmente l'efficacité du butinage de nectar, en plus de l'accroissement bien connu de l'intensité. On a réalisé une expérience d'amassement, dans laquelle les abeilles pouvaient amasser simultanément des solutions de saccharose à $20 \%$ et $50 \%$. De l'eau était également fournie. Les cagettes d'abeilles ont atteint une efficacité de 0,20 (calculée d'après le nombre total de grammes de sucre/nombre total de grammes de solution) si $20 \%$ seulement de la solution était amassée et une efficacité de 0,50 si $50 \%$ seulement de la solution était amassée et une efficacité intermédiaire entre ces deux extrêmes. Les abeilles des cages peu pourvues de rayons ont une efficacité moyenne de 0,38 , tandis que celles des cages copieusement pourvues en rayons atteignent une efficacité moyenne de 0,40 , significativement plus élevée ( $\mathrm{P} 0,003$ ). Ce résultat confirme l'hypothèse selon laquelle la stimulation due aux rayons vides régule l'efficacité de sorte que des abeilles d'autant plus stimulées sélectionnent des solutions d'autant plus concentrées.

\section{ZUSAMMENFASSUNG}

REGULATION DES WIRKUNGSGRADES DES FUTTEREINLAGERNS DER HONIGBIENE

Frühere Feldversuche haben ergeben, daß zusätzliche leere Waben in einem Volk den Wirkungsgrad des Nektareintragens verbessern, zusätzlich zu der noch besser dokumentierten Intensitätssteigerung.

Es wurde ein Versuch zum Futtereintragen durchgeführt, bei dem die Bienen gleichzeitig an einer $20 \%$ igen und an einer $50 \%$ igen Zuckerlösung sammeln konnten. Wasser wurde ebenfalls geboten. Die Käfige konnten also einen Wirkungsgrad von 0,20 erreichen (errechnet aus den totalen Gramm Zucker/totale Gramm der Lösung), wenn nur von der $20 \%$ igen Lösung eingetragen wurde, oder einen Wirkungsgrad von 0,50 , wenn nur $50 \%$ ige Lösung gesammelt wurde, oder einen Wirkungsgrad, der irgendwo zwischen diesen beiden Extremen liegt. 
Bienen in Käfigen mit wenig Wabenraum speichern mit einem mittleren Wirkungsgrad von 0,38 , während Bienen in Käfigen mit ausreichend Wabenraum einen signifikant höheren mittleren Wirkungsgrad von 0,40 hatten $(p<0,003)$.

Dieses Ergebnis stützt die Hypothese, daß die Stimuliering durch leere Waben den Wirkungsgrad in der Weise reguliert, daß mehr stimulierte Bienen sich stärker für das konzentriertere Futter entscheiden.

\section{REFERENCES}

Bосн R., 1957. - Rassenmässige Unterschiede bei den Tänzen de Honigbiene (Apis mellifica L.). Z. vergl. Physiol, 40, 289-320.

Crane E., 1975. - The flowers honey comes from. pp. 3-55. In Crane, E. (ed.), Honey. Heinemann, London. $608 \mathrm{pp}$.

Esch H., 1961a. - Ein neuer Bewegungstyp im Schwänzeltanz der Bienen. Naturwissenschaften, 48, $140-141$.

Esch H., 196lb. - Über die Schallerzeugung beim Werbetanz der Honigbiene. Z. vergl. Physiol., 45, 1-11.

Free J. B. and I. H. Williams, 1972. - Hoarding by honeybees (Apis mellifera L.). Anim. Behav., 20, 327-334.

FrISCH K. von, 1967. - The dance language and orientation of bees. Belknap Press of Harvard Univ. Press, Cambridge. 566 pp.

KULINČEVIČ J. M. and W. C. ROTHENBUHLER, 1973. - Laboratory and field measurements of hoarding, behaviour in the honeybee (Apis mellifera). J. Apic. Res., 12, 179-182.

Lindauer M., 1948. - Über die Einwirkung von Duft- und Geschmacksstoffen sowie anderer Faktoren auf die Tänze der Bienen. Z. vergl. Physiol., 31, 348-412.

Oertel E., T. E. Rinderer and B. G. Harville, 1980. - Changing trends in southeastern Louisiana honey production through 25 years. Am. Bee J., 120, 763-765.

RINDERER T. E., 1981. - Volatiles from empty comb increase hoarding by the honey bee. Anim. Behav., 29, 1275-1276.

Rinderer T. E., 1982. - Regulated nectar-harvesting of the honeybee. J. Apic. Res., 21, 74-87.

RINDERER T. E. and J. R. BAXTER, 1978. - Effect of empty comb on hoarding behavior and honey production of the honey bee. J. Econ. Entomol., 71, 757-759.

Rinderer T. E. and J. R. BAXTER, 1979. - Honey bee hoarding behaviour: Effects of previous stimulation by empty comb. Anim. Behav., 27, 426-428.

RiNDERER T. E. and J. R. BAXTER, 1980. - Hoarding behavior of the honey bee : Effects of empty comb, comb color, and genotype. Environ. Entomol., 9, 104-105.

Sylvester H. A., T. E. Rinderer and A. B. Bolten, 1983. - Honey-sac contents : A technique for collection and measurement in foraging honey bees. J. Econ. Entomol, 76, 204-206.

Waddington K.E., 1981. - Patterns of size variation in bees and evolution of communication systems. Evol., 35, 813-814.

Waddington K. D. and L. R. Holden, 1979. - Optimal foraging : On the flower selection by bees. Am. Nat. 114, 179-196. 